\title{
Pemanfaatan Fitur Analisis Data Menggunakan K-Means Cluster Dalam Point of Sales (POS)
}

\author{
Supangat \\ Program Studi Teknik Informatika \\ Universitas 17 Agustus 1945 Surabaya \\ supangat@untag-sby.ac.id
}

\author{
Anis R. Amna \\ Program Studi Teknik Informatika \\ Universitas 17 Agustus 1945 Surabaya \\ anis.r.amna@gmail.com
}

\begin{abstract}
Abstrak - Pemanfaatan big data untuk meningkatkan performa usaha banyak menjadi pembahasan penelitian akhir-akhir ini. Ketersediaan data yang mampu diakses secara cepat untuk mereproduksi informasi baru yang penting dalam pengambilan keputusan menjadi salah satu faktor kunci yang menentukan keberhasilan organisasi. K-Means cluster sebagai salah satu algoritma data mining dengan kemampuan pengelompokan data merupakan salah satu tools yang penting untuk melakukan hal ini. Penelitian ini akan membahas implementasi algoritma $K$-Means untuk menghasilkan informasi baru berupa klasifikasi kelompok produk berdasarkan data transaksi penjualan di masa lalu. Algoritma ini selanjutnya akan menjadi fitur pada Sistem Informasi Point of Sales (POS) yang dikembangkan. Dengan adanya fitur baru pada sistem informasi POS, diharapkan pemilik usaha dapat merencanakan jumlah dan waktu pembelian produk dengan lebih baik, mengurangi jumlah persediaan barang di gudang, dan memberikan keleluasaan bagi pemilik usaha untuk menganalisis permintaan dengan mudah.
\end{abstract}

Kata Kunci: Knowledge Management, K-Means Clustering, Rancang Bangun Sistem Informasi, Sistem Informasi Eksekutif, Use Case Driven Model.

\section{PENDAHULUAN}

Pemanfaatan data dan informasi untuk meningkatkan kinerja perusahaan telah ramai menjadi topik pembahasan di bidang knowledge management (KM). Hal ini terjadi karena KM dianggap memainkan peran penting untuk meningkatkan nilai kolaborasi bisnis di dalam perusahaan. Pemanfaatan teknologi berbasis data seperti robotics, kecerdasan buatan, serta digitalisasi memungkinkan pelanggan untuk memperoleh pelayanan personal serta mengoptimalkan proses bisnis perusahaan pada saat bersamaan [1].

Dalam pembahasan lain, pemanfaatan KM dalam bisnis dipercaya mempengaruhi proses pengambilan keputusan secara rasional, yang pada akhirnya mampu meningkatkan performa organisasi. Hal ini disebabkan karena KM memungkinkan adanya kolaborasi antar berbagai disiplin ilmu yang didukung oleh pemanfaatan teknologi informasi dalam berbagai bentuk serta kemampuan perusahaan untuk terus belajar mengoptimalkan proses bisnis yang ada sehingga melahirkan pengetahuan baru yang lebih baik [2].

Kemampuan perusahaan dalam memahami kebutuhan pelanggan merupakan salah satu faktor penting yang mempengaruhi kinerja organisasi. Tanpa pemahaman yang menyeluruh tentang keinginan pelanggan dan kondisi perusahaan, pemilik usaha akan mengambil keputusan menggunakan intuisinya. Oleh karena itu, fitur data mining dalam sistem informasi manajemen diperlukan untuk mengungkap informasi yang tersembunyi dalam data transaksi yang telah ada yang pada akhirnya memungkinkan pemilik usaha untuk membuat keputusan berdasarkan data dan mentransformasikannya dalam bentuk kebijakan bisnis yang bermanfaat untuk proses bisnisnya [3].

K-Means Clustering merupakan salah satu teknik data mining menggunakan strategi unsupervised learning. Strategi ini memiliki kemampuan untuk menemukan dan mengelompokkan data secara otomatis berdasarkan karakteristik tertentu yang tersembunyi di dalam data [4]. Meskipun memiliki potensi yang sangat besar, namun penggunaan K-Means sebagai salah satu fitur POS yang berfungsi memberikan rekomendasi pembelian produk di masa yang akan datang masih terbatas. Oleh karena itu, penelitian ini fokus pada implementasi fitur analisis data menggunakan $K$-Means yang akan memberikan rekomendasi pengambilan keputusan pembelian produk bagi pemilik usaha.

\section{LANDASAN TEORI}

\section{A. Knowledge Management dan Data Mining}

Knowledge Management dapat diartikan sebagai paradigma, framework, konsep, fungsi, maupun nilai yang berfungsi mendukung individu maupun organisasi untuk mengelola nilai yang dimiliki [5]. Dalam terminologi yang lain, KM juga dapat dipahami sebagai proses identifikasi, pengumpulan, dan pengkodean pengetahuan eksplisit yang telah ada baik dalam bentuk prosedur, dokumen, maupun kebijakan yang sebelumnya tidak terekam secara implisit yang dapat bermanfaat bagi orang lain [6]. Sehingga secara umum KM dapat dipahami sebagai serangkaian metode, framework, maupun konsep untuk mengumpulkan pengetahuan yang berasal dari individu atau kelompok dan 
mengelolanya untuk menghasilkan manfaat bagi banyak orang.

Perkembangan teknologi internet khususnya dalam bidang database, data warehouse, machine learning, dan manajemen berbasis pengetahuan telah banyak mempengaruhi cara organisasi untuk memenangkan kompetisi. Pengetahuan yang tersembunyi di dalam aktivitas operasional perusahaan telah banyak disadari sebagai faktor kunci untuk mendukung berbagai keputusan organisasi [3]. Sebagai sebuah teori, DM didefinisikan sebagai proses yang menggunakan teknik-teknik statistika, matematika, kecerdasan buatan dan machine learning untuk mengekstrak dan mengidentifikasi informasi yang bermanfaat dan mengubahnya menjadi pengetahuan yang bersumber dari database [7]. Pemanfaatan data mining (DM) dalam proses penemuan pengetahuan yang tersimpan di dalam database mampu menyediakan berbagai metodologi pengambilan keputusan, penyelesaian masalah, analisis dan perencanaan, diagnosis, deteksi, integrase, sampai pada penyediaan tindakan preventif, pembelajaran, maupun motivasi.

\section{B. K-Means Clustering}

K-Means Clustering merupakan salah satu algoritma pengklasteran yang mudah digunakan dan memiliki efisiensi komputasi yang tinggi. Meskipun demikian, algoritma ini memiliki sensitifitas yang cukup tinggi pada centroid [8]. Pada clustering berbasis centroid, sejumlah titik awal data tertentu diinisiasi sebagai centroid awal. Selanjutnya, pengelompokan data dilakukan secara iteratif melalui penghitungan jarak masing-masing objek observasi terhadap titik centroid terdekat hingga mencapai kriteria tertentu [9].

Secara umum metode K-Means dilakukan mengikuti algoritma berikut:

1. Menentukan jumlah kelas cluster

2. Menentukan titik centroid awal

3. Menghitung jarak antara data dengan centroid menggunakan rumus jarak Euclidean sebagai berikut:

$$
\begin{aligned}
d(p, q)=d(q, p) & =\sqrt{\left(q_{1}-p_{1}\right)^{2}+\left(q_{2}-p_{2}\right)^{2}+\ldots+\left(q_{11}-p_{i 1}\right)^{2}} \\
& =\sqrt{\sum_{i=1}^{\pi}\left(q_{1}-p_{1}\right)^{2}}
\end{aligned}
$$

4. Menghitung rata-rata data dari setiap kelas menggunakan rumus sebagai berikut:

$$
m_{i}^{(t+1)}=\frac{1}{\left|s_{i}^{(t)}\right|} \sum_{x_{f \in s_{i}}} x_{j}
$$

5. Untuk seluruh kelas, jika perbedaan antara nilai means dan centroid > nilai error, ganti nilai centroid dengan rata-rata nilai kelas dan ulangi langkah 3 .

\section{Sistem Informasi Eksekutif}

EIS merupakan sistem yang didesain untuk memenuhi kebutuhan eksekutif, merupakan gabungan dari sistem informasi enterprise dan teknologi web yang menyandarkan sebagian besar prosesnya pada manajemen data [10]. Selain berfungsi memberikan rekomendasi yang lebih baik bagi pengambil keputusan, EIS memiliki beberapa kelebihan sebagai berikut [11]:

1. Akses yang lebih cepat pada database dan informasi

2. Informasi yang lebih relevan dan terbaru

3. Meningkatkan kemampuan untuk mengidentifikasi riwayat tren di masa lalu

4. Meningkatkan efekfitivas dan efisiensi di kalangan eksekutif.

\section{METODOLOGI PENELITIAN}

Metodologi yang digunakan pada penelitian ini menggunakan pendekatan research and development (R\&D). Metode ini dipilih dengan mempertimbangkan produk yang dihasilkan dan kontribusi yang dapat diberikan kepada masyarakat [12]. Pada proses ini dilakukan tahap-tahap sebagai berikut:

1. Pengumpulan Data Sampel

2. Analisis Data dan Pembuatan Model K-Means

3. Pengembangan Sistem Informasi POS

4. Pengujian Efektivitas Fitur Analisis Data Menggunakan $K$-Means sebagai fitur POS

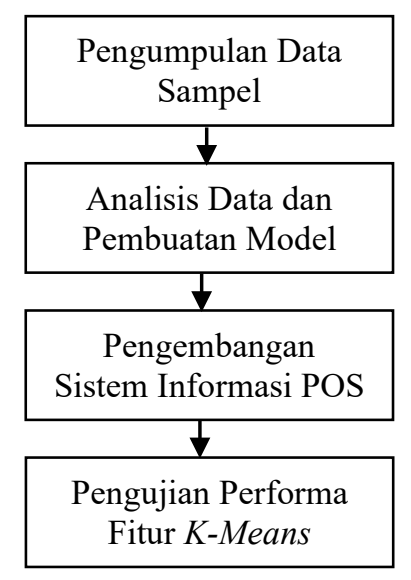

Gambar 1. Metodologi Penelitian

\section{HASIL DAN PEMBAHASAN}

\section{A. Pengumpulan Data Sampel}

Data sampel diperoleh dari 27.000 data transaksi penjualan spare part kendaraan bermotor di sebuah toko di Surabaya selama 1 tahun. Pemilihan data sampel ini dikhususkan pada produk kendaraan roda 2 dengan pertimbangan besarnya jumlah pembelian dan efisiensi persediaan barang di gudang. 
Tabel 1. Data Transaksi Penjualan 76 Jenis Produk Sparepart Selama 1 Tahun Terakhir

\begin{tabular}{|c|c|c|c|c|c|}
\hline ID_Brg & Harga & $\begin{array}{l}\text { Jml } \\
\text { Jual }\end{array}$ & ID_Brg & Harga & $\begin{array}{l}\text { Jml } \\
\text { Jual }\end{array}$ \\
\hline 1 & 88000 & 1 & 39 & 30250 & 9 \\
\hline 2 & 88000 & 2 & 40 & 90000 & 16 \\
\hline 3 & 93500 & 3 & 41 & 120000 & 10 \\
\hline 4 & 88000 & 229 & 42 & 82500 & 17 \\
\hline 5 & 102000 & 62 & 43 & 95000 & 18 \\
\hline 6 & 102000 & 36 & 44 & 160000 & 7 \\
\hline 7 & 93500 & 20 & 45 & 90000 & 71 \\
\hline 8 & 120000 & 213 & 46 & 104500 & 351 \\
\hline 9 & 110000 & 1179 & 47 & 69000 & 9 \\
\hline 10 & 50000 & 339 & 48 & 104500 & 6 \\
\hline 11 & 27500 & 336 & 49 & 129500 & 229 \\
\hline 12 & 27500 & 3323 & 50 & 72600 & 190 \\
\hline 13 & 35100 & 80 & 51 & 32000 & 28 \\
\hline 14 & 25000 & 1573 & 52 & 71500 & 428 \\
\hline 15 & 65000 & 1013 & 53 & 77000 & 366 \\
\hline 16 & 65000 & 83 & 54 & 33000 & 230 \\
\hline 17 & 92000 & 81 & 55 & 12000 & 237 \\
\hline 18 & 39000 & 452 & 56 & 23500 & 374 \\
\hline 19 & 63500 & 543 & 57 & 27000 & 113 \\
\hline 20 & 110000 & 507 & 58 & 30000 & 39 \\
\hline 21 & 150000 & 148 & 59 & 34000 & 191 \\
\hline 22 & 175000 & 2 & 60 & 25000 & 450 \\
\hline 23 & 60000 & 12 & 61 & 26000 & 277 \\
\hline 24 & 120000 & 12 & 62 & 27500 & 393 \\
\hline 25 & 30000 & 3 & 63 & 26000 & 40 \\
\hline 26 & 40000 & 4 & 64 & 28350 & 303 \\
\hline 27 & 45000 & 107 & 65 & 29000 & 40 \\
\hline 28 & 33000 & 1184 & 66 & 30500 & 40 \\
\hline 29 & 28000 & 429 & 67 & 27500 & 403 \\
\hline 30 & 33000 & 589 & 68 & 31500 & 17 \\
\hline 31 & 63500 & 131 & 69 & 29000 & 814 \\
\hline 32 & 102000 & 14 & 70 & 31500 & 845 \\
\hline 33 & 125000 & 16 & 71 & 8000 & 325 \\
\hline 34 & 150000 & 4 & 72 & 7500 & 78 \\
\hline 35 & 65000 & 10 & 73 & 8000 & 102 \\
\hline 36 & 60000 & 5 & 74 & 31500 & 70 \\
\hline 37 & 60000 & 960 & 75 & 10000 & 151 \\
\hline 38 & 31000 & 6335 & 76 & 34000 & 406 \\
\hline
\end{tabular}

B. Analisis Data dan Pembuatan Model

Berdasarkan data awal dilakukan proses clustering menggunakan pendekatan K-Means. Pada proses K-Means ditentukan jumlah cluster yang akan dihasilkan sebanyak 3 cluster, yaitu cluster penjualan rendah, penjualan sedang, dan penjualan tinggi. Penentuan centroid awal ditentukan secara random sesuai Tabel 2 berikut.

Tabel 2. Centroid Awal

\begin{tabular}{rrrr} 
Cluster & P1 & P2 \\
\hline $\mathbf{1}$ & 7500 & 78 \\
\hline $\mathbf{2}$ & 102000 & 14 \\
\hline $\mathbf{3}$ & 175000 & 2 \\
\hline
\end{tabular}

Selanjutnya proses penghitungan means dan update nilai centroid terus dilakukan hingga tidak ada perubahan keanggotaan pada masing-masing cluster. Setelah iterasi ke 22, diperoleh hasil cluster untuk masing-masing data seperti pada Tabel 3 berikut.

Tabel 3. Hasil Akhir Analisis Cluster Menggunakan K-Means

\begin{tabular}{|c|c|c|c|c|c|}
\hline id_brg & cluster & id_brg & cluster & id_brg & cluster \\
\hline 1 & 2 & 27 & 1 & 53 & 2 \\
\hline 2 & 2 & 28 & 1 & 54 & 1 \\
\hline 3 & 2 & 29 & 1 & 55 & 1 \\
\hline 4 & 2 & 30 & 1 & 56 & 1 \\
\hline 5 & 2 & 31 & 1 & 57 & 1 \\
\hline 6 & 2 & 32 & 2 & 58 & 1 \\
\hline 7 & 2 & 33 & 2 & 59 & 1 \\
\hline 8 & 2 & 34 & 3 & 60 & 1 \\
\hline 9 & 2 & 35 & 1 & 61 & 1 \\
\hline 10 & 1 & 36 & 1 & 62 & 1 \\
\hline 11 & 1 & 37 & 1 & 63 & 1 \\
\hline 12 & 1 & 38 & 1 & 64 & 1 \\
\hline 13 & 1 & 39 & 1 & 65 & 1 \\
\hline 14 & 1 & 40 & 2 & 66 & 1 \\
\hline 15 & 1 & 41 & 2 & 67 & 1 \\
\hline 16 & 1 & 42 & 2 & 68 & 1 \\
\hline 17 & 2 & 43 & 2 & 69 & 1 \\
\hline 18 & 1 & 44 & 3 & 70 & 1 \\
\hline 19 & 1 & 45 & 2 & 71 & 1 \\
\hline 20 & 2 & 46 & 2 & 72 & 1 \\
\hline 21 & 3 & 47 & 2 & 73 & 1 \\
\hline 22 & 3 & 48 & 2 & 74 & 1 \\
\hline 23 & 1 & 49 & 3 & 75 & 1 \\
\hline 24 & 2 & 50 & 2 & 76 & 1 \\
\hline 25 & 1 & 51 & 1 & & \\
\hline 26 & 1 & 52 & 2 & & \\
\hline
\end{tabular}


Sehingga, berdasarkan Tabel 3 dapat disimpulkan bahwa $60,5 \%$ data merupakan produk dengan kategori tingkat penjualan tinggi, 32,9\% merupakan produk dengan tingkat penjualan sedang, dan $6,6 \%$ produk merupakan produk dengan tingkat penjualan rendah (Tabel 4).

Table 4. Presentase Tingkat Penjualan Produk berdasarkan Cluster

\begin{tabular}{rrr} 
Cluster & Jumlah Data & Persen \\
\hline $\mathbf{1}$ & 46 & $60,5 \%$ \\
\hline $\mathbf{2}$ & 25 & $32,9 \%$ \\
\hline $\mathbf{3}$ & 5 & $6,6 \%$ \\
\hline
\end{tabular}

\section{Pengembangan Sistem Informasi POS}

Untuk menentukan produk-produk yang masuk dalam kategori tingkat penjualan tinggi, sedang, dan rendah, dibuatlah alat bantu berupa fitur POS yang dapat digunakan pemilik usaha untuk melakukan pembelian ulang produk.

Sistem informasi POS dengan fitur analisis $K$-Means ini dikembangkan menggunakan pendekatan pengembangan waterfall dengan perancangan sistem menggunakan pendekatan usecase driven object.

Kemampuan fungsional yang diperlukan pengguna terhadap sistem POS tersebut dapat didefinisikan sebagai berikut:

1. Bagian gudang dapat menginputkan barang masuk

2. Bagian gudang dapat mengupdate stok barang

3. Bagian gudang dapat mengajukan retur

4. Kasir dapat melakukan input data penjualan

5. Kasir dapat mencetak laporan penjualan

6. Bagian pembelian dapat melakukan analisis data

7. Bagian pembelian dapat mengajukan rencana pembelian

8. Bagian pembelian dapat mencetak laporan analisis data

9. Pemilik toko dapat melakukan analisis data

10. Pemilik toko dapat melihat hasil analisis data

11. Pemilik toko dapat mencetak laporan penjualan

12. Pemilik toko dapat mencetak laporan pembelian

13. Pemilik toko dapat mencetak hasil analisis data

14. Pemilik toko dapat menginput data supplier

15. Pemilik toko dapat melihat piutang jatuh tempo

Berdasarkan kebutuhan fungsional tersebut maka dapat disusun use case dengan empat rule actor, yaitu pemilik, bagian gudang, kasir, dan bagian pembelian seperti yang dapat dilihat pada Gambar 2. Selain fitur standar dari POS yang memiliki kemampuan dokumentasi data, sistem informasi yang dikembangkan juga dilengkapi dengan fitur analisis data yang mengimplementasikan metode $K$-Means sesuai dengan simulasi model manual yang telah dilakukan sebelumnya.

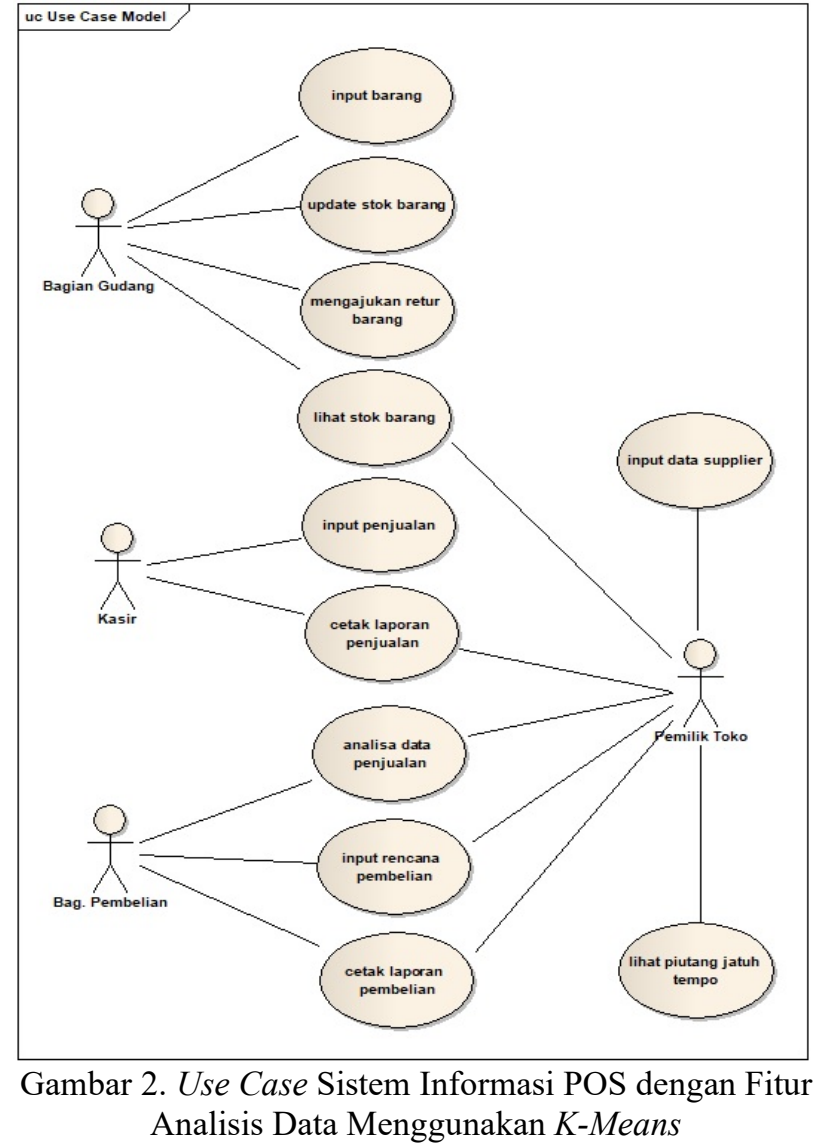

Bagian pembelian dapat mengakses fitur analisis data untuk mengetahui tren penjualan barang pada periode tertentu. Selain itu, pemilik toko juga dapat memanfaatkannya untuk memonitor kondisi persediaan barang. Untuk memanfaatkan fitur ini, baik bagian pembelian maupun pemilik toko harus melakukan seleksi periode data yang akan dianalisis pada halaman analisis data. Selanjutnya, sistem akan menampilkan rekomendasi dari $K$ Means di halaman analisis data. Untuk mencetak rekomendasi hasil analisis data, pengguna data dapat memilih tombol cetak yang terdapat di halaman analisis data. Proses ini secara detil dapat dilihat pada robustness diagram pada gambar 3 berikut.

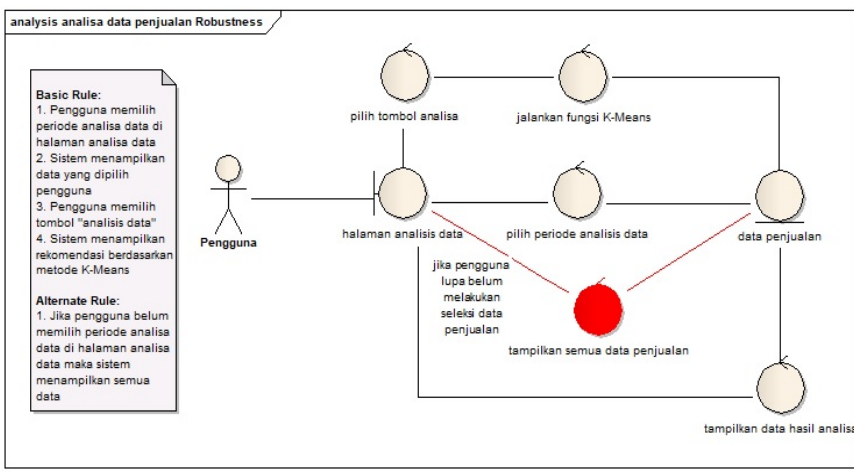

Gambar 3. Robustness Diagram Analisis Data Menggunakan K-Means 


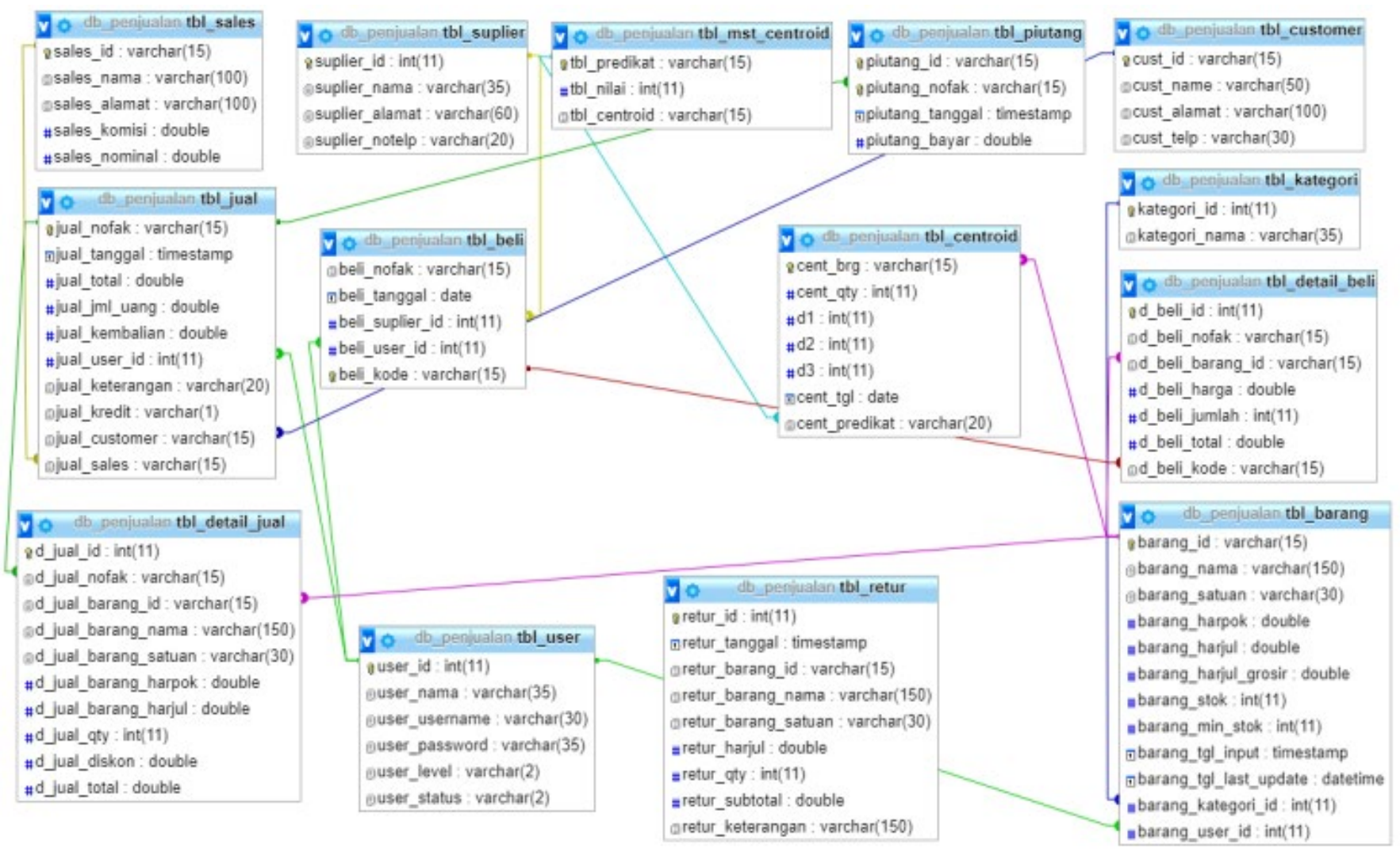

Gambar 4. Database Sistem Informasi POS Dengan Fitur Analisis Data Menggunakan K-Means

Sebagai media penyimpanan dari sistem informasi POS, maka dibuatlah database seperti terlihat pada Gambar 4 di atas. Setelah diimplementasikan, sistem informasi POS dengan fitur analisis data memiliki tampilan awal yang dapat dilihat pada Gambar 5. Selain memiliki menu yang terletak di atas aplikasi, sistem juga dilengkapi dengan shortcut berupa menu-menu yang paling sering digunakan dalam sistem POS, antara lain: penjualan eceran, sales, supplier, barang, pembelian, dan laporan.

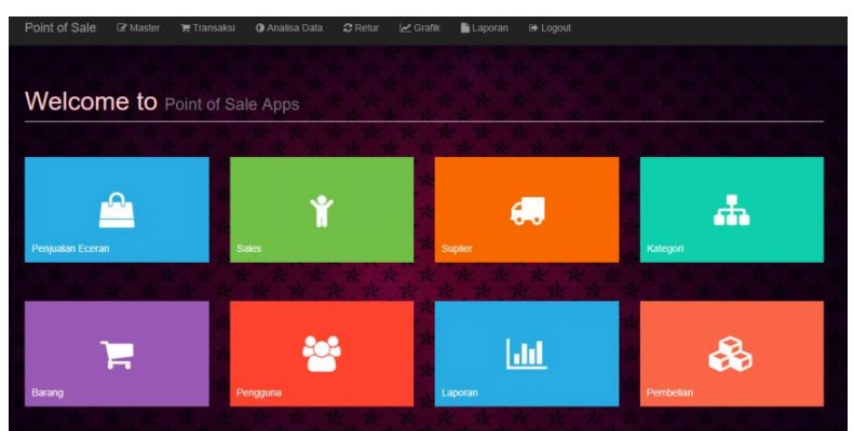

Gambar 5. Tampilan Pada Halaman Awal Sistem Informasi POS Dengan Fitur Analisis Data K-Means

Pada Gambar 6, fitur analisis data terletak di atas sistem informasi dan terbatas hanya dapat diakses oleh pemilik toko dan bagian pembelian. Penentuan centroid ter update otomatis setelah pengguna memilih periode tanggal awal dan akhir transaksi dan mengklik tombol proses, dan jika pengguna tidak memilih data transaksi maka secara default sistem akan mengacak data centroid awal.

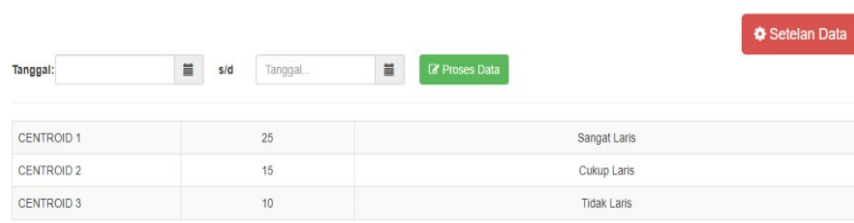

Gambar 6. Fitur Analisis Data Menggunakan K-Means Cluster

Setelah pengguna mengklik tombol proses data, maka sistem akan menampilkan hasil rekomendasi berupa data produk untuk masing-masing cluster. Selain itu, informasi juga dilengkapi dengan rata-rata jumlah penjualan pada periode tertentu (Gambar 7).

D. Pengujian Performa Fitur Analisis Data K-Means

Pengujian performa penggunaan metode $K$-Means pada studi kasus penjualan produk sparepart menunjukkan tingkat error sebesar 14,47\%. Sehingga dapat disimpulkan bahwa metode $K$-Means memiliki tingkat akurasi sebesar 85,53\%. 


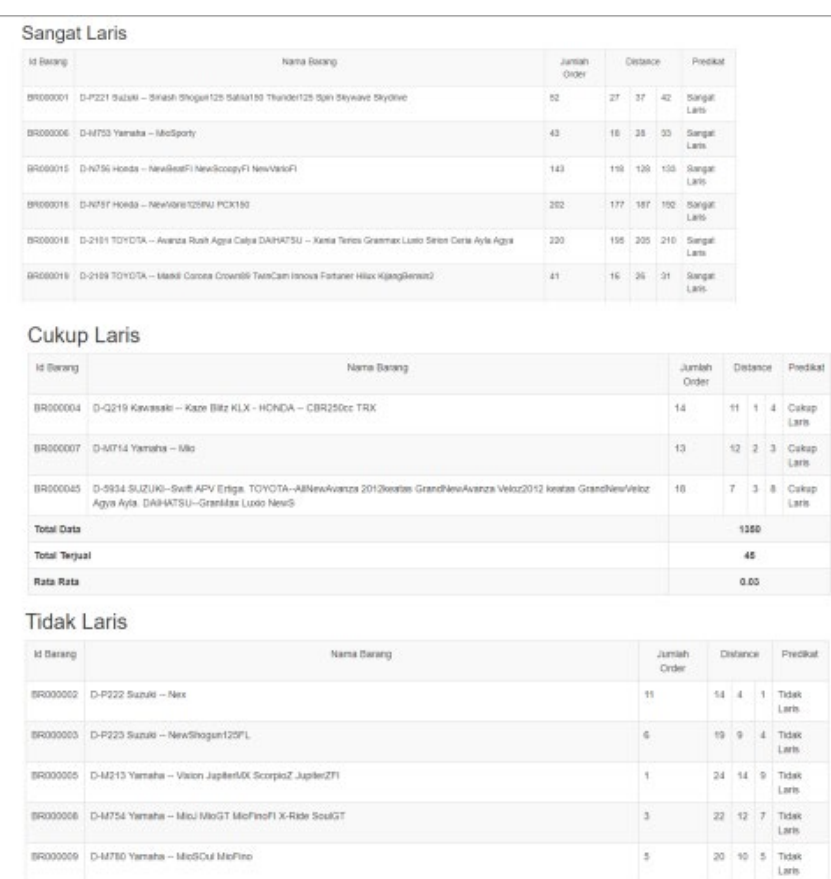

Gambar 7 Tampilan Rekomendasi K-Means Cluster Untuk Fitur Analisis Data

\section{KESIMPULAN}

Penambahan fitur analisis data menggunakan pendekatan K-Means clustering pada sistem informasi POS dapat memberikan nilai tambah bagi pemilik usaha untuk merencanakan pembelian dengan lebih baik. Selain itu, rekomendasi yang diberikan dalam bentuk fitur dalam sistem informasi POS dapat digunakan dengan mudah sehingga dapat meningkatkan efisiensi organisasi. Penggunaan fitur $K$-Means secara signifikan juga terbukti memiliki tingkat akurasi yang tinggi yaitu sebesar $85,53 \%$ sehingga dalam jangka panjang metode ini dapat terus digunakan sebagai salah satu fitur decision support system bagi perusahaan.

\section{REFERENSI}

[1] Paschek, D. \& Draghici, A. (2018). Knowledge Management - The Foundation for a Successful Business Process Management. Procedia - Soc. Behav.
Sci., Vol. 238, pp. 182-191.

[2] Abubakar, A.M., Elrehail, H., Alatailat, M.A. \& Elçi, A. (2017). Knowledge Management, Decision-Making Style and Organizational Performance. J. Innov. Knowl., pp. 1-15.

[3] Shaw, M.J., Subramaniam, C., Woo, G. \& Welge, M.E. (2001). Knowledge Management and Data Mining for Marketing. Decis. Support Syst., Vol. 31, pp. 127-137.

[4] Thomas, M.C., Zhu, W. \& Romagnoli, J.A. (2017). Data Mining and Clustering in Chemical Process Databases for Monitoring and Knowledge Discovery. $J$. Process Control.

[5] Tsai, H. (2013). Knowledge Management vs. Data Mining: Research Trend, Forecast and Citation Approach. Expert Syst. Appl., Vol. 40, No. 8, pp. 3160 3173

[6] Cooper, P. (2016). Data, Information, Knowledge, and Wisdom. Anaesth. Intensive Care Med., pp. 1-2.

[7] Turban, E., Aronson, J.E. \& Liang, T.P. (2007). Decision Support Systems and Business Intelligence. Decis. Support Bus. Intell. Syst. 7/E, pp. 1-35.

[8] Majhi, S.K. \& Biswal, S. (2018). Optimal Cluster Analysis Using Hybrid K-Means and Ant Lion Optimizer. Karbala Int. J. Mod. Sci., Vol. 4, No. 4, pp. 347-360.

[9] Ben, S., Naouali, S. \& Chtourou, Z. (2018). A Fast and Effective Partitional Clustering Algorithm for Large Categorical Datasets Using a K-Means Based Approach. Comput. Electr. Eng., Vol. 68, April, pp. 463-483.

[10] Koh, C.E. \& Watson, H.J. (1998). Data Management in Executive Information Systems. Inf. Manag., Vol. 33, pp. 301-312.

[11] Turban, E., Sharda, R. \& Delen, D. (2011). Decision Support and Business Intelligence Systems. Pearson Education International.

[12] Yoshikawa, H. (2012). Design Methodology for Research and Development Strategy. Japan: Center for Research and Development Strategy, Japan Science and Technology Agency. 